\title{
Corrigendum
}

\section{Biomimetic protein-harpooning surfaces - CORRIGENDUM}

G.M.L. Messina, C. Bonaccorso, A. Rapisarda, B. Castroflorio, D. Sciotto, and G. Marletta

doi: https://doi.org/10.1557/mrc.2018.54, Published by Materials Research Society with Cambridge University Press, 6 April 2018

In Messina et al., ${ }^{1}$ references 9 and 18 were provided with incorrect publication years. The references are corrected below.

9. M. Dettin, A. Zamuner, M. Roso, A. Gloria, G. Iucci, G.M.L. Messina, U. D’Amore, G. Marletta, M. Modesti, I. Castagniulo, and P. Brun: Electrospun scaffolds for osteoblast cells: peptide-induced concentration- dependent improvements of polycaprolactone. PLoS ONE 10, e0137505 (2015)

18. T. Mecca, G. M. L. Messina, G. Marletta, and F. Cunsolo: Novel pH responsive calix[8]arene hydrogelators: self-organization processes at a nanometric scale. Chem. Commun. 49, 2530 (2013).

\section{Reference}

1.G.M.L. Messina, C. Bonaccorso, A. Rapisarda, B. Castroflorio, D. Sciotto, and G. Marletta: Biomimetic protein-harpooning surfaces. MRS Communications 8 , $241-247$. 